\title{
AFTER-HATCHING-YEAR SUBADULT COMMON LOONS IN MANITOBA
}

GORD HAMMELL, Erickson, MB, ROJOPO;

Email: hammell@inetlinkwireless.ca

The common loon (Gavia immer) is familiar to most Canadians, breeding across Canada in suitable lakes and rivers and in most cases, migrating south to coastal waters in winter. ${ }^{1,2}$ Population trends from the annual Breeding Bird Survey (1970-2009) ${ }^{3}$ suggest increasing populations for Canada and Manitoba but a slight decrease for Prairie Potholes Bird Conservation Region (Fig.1). The area south of Riding Mountain National Park in southwestern Manitoba is "pothole" country within this Region and the topography is rolling with numerous lakes and ponds interspersed
29-June 2, and June 6-10) produced respectively, zero, five, and four adult individuals in breeding plumage. No chicks were seen on the study area but were observed on lakes within $400 \mathrm{~m}$ of the boundary.

While conducting waterfowl brood counts in the early morning on June 29,2011 , I observed a large whitelooking bird on a 16 ha lake $(50.43083$, -99.724717) 11km southeast of Erickson. I initially assumed that it was a gull because it appeared so white. The bird was at $\sim 100 \mathrm{~m}$ distance and

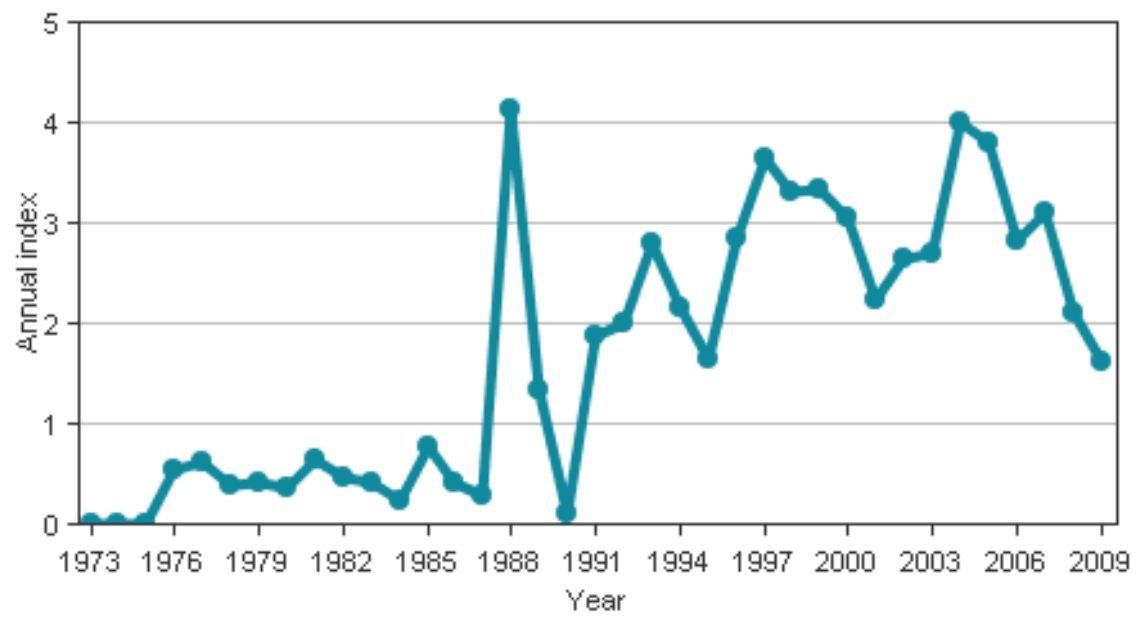

Figure 1. Annual indices of population change for the Common Loon in Manitoba based on Breeding Bird Survey data (1973 - 2009). Trend +15.5

with agricultural lands. I have been conducting waterfowl surveys in this area near Erickson (Fig 2) for several years and have regularly seen common loons (hereafter loon) occupying and successfully raising young in the area. For example, in 2011 on a $22 . \mathrm{km}^{2}$ ( 9 sq miles) study area, counts conducted over three time periods (May 23-25, May upon closer examination with a 20-60x spotting scope, I realized that the bird was facing me and was a loon. No other loons were on the lake. The observed whitish glow was from its white breast, neck and throat. The back of the bird was greyish. I immediately assumed that this was a juvenile bird from the previous year but was surprised to see 


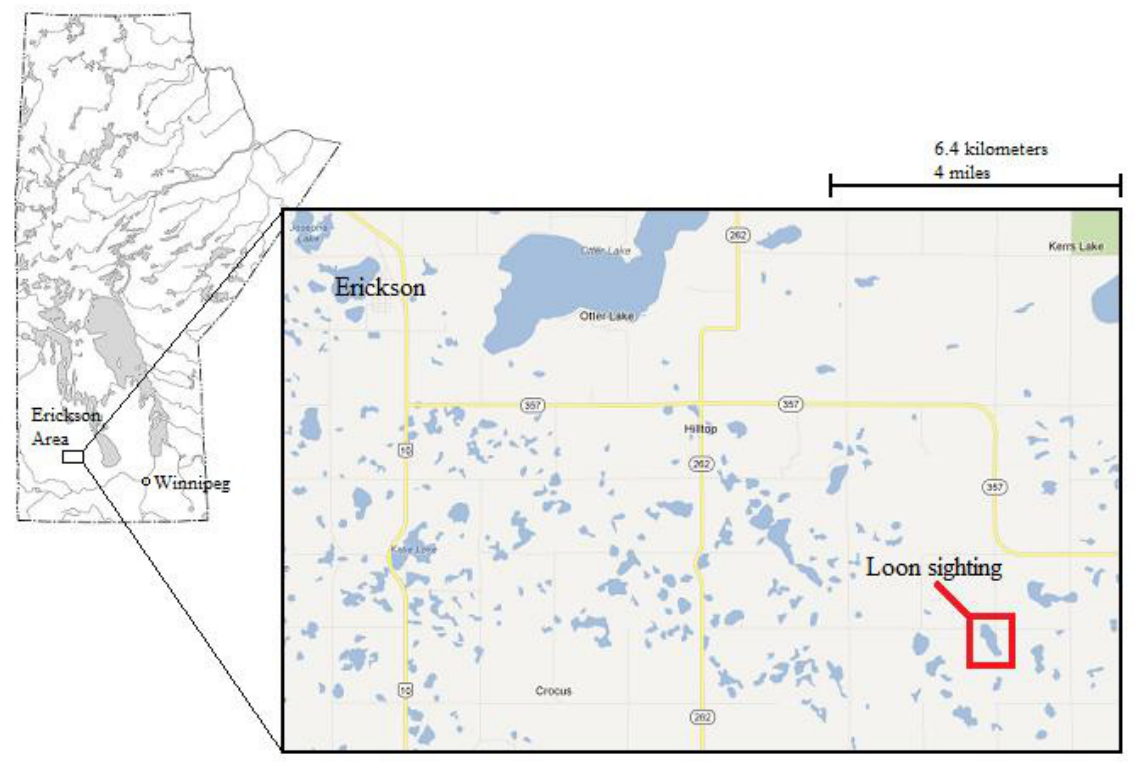

Figure 2. Location of common loon sighting near Erickson, $M B$

it as I could not remember seeing a juvenile of this size and colour except in the late summer and early fall. Loon chicks in late June in this area are downy and much smaller. I returned to my birding books and discovered that this bird was most likely a subadult ; ie: a juvenile from a previous year in basic plumage. If a subadult, then this bird should be on or near salt water for several years (usually three to five) , $^{4,(\mathrm{C} C}$. walcott, pers.comm.) before returning to breeding areas in breeding (alternate) plumage. I revisited the lake the next morning, found the bird still in the same spot and examined it more carefully. I noted a white partial triangular collar on the sides of the neck, a diagnostic characteristic of basic- plumaged birds and a mottled back of brown, black, and white, giving a greyish appearance. It lacked all of the plumage characteristics of an adult in breeding plumage.

I returned to the lake in one week and the bird was gone and was not knowingly seen by me again in the area (this bird might have been confused with some young-of-the-year later in the summer).

My interest was aroused so I contacted several experienced birders in Manitoba, Saskatchewan and Ontario and asked if they had observed these birds in spring or early summer. In Manitoba, one observer recorded five May-July sightings since 1977 in Pinawa area (P. Taylor, Fig. 3) and another recorded one sighting in Riding Mountain National Park in May, 1984 (C. Cuthbert). Another from southwestern Manitoba has not seen loons in basic plumage in spring or early summer (K. Kingdon). For Saskatchewan, I was unable to find anyone who had seen one of these birds (S. Houston, T.Stene, R.Wilson). Although far from a comprehensive survey, the scarcity of sightings suggests that basic-plumaged birds are infrequent (but perhaps regular?) visitors to Manitoba inland breeding grounds in spring and summer. Discussions with these observers 
suggest that the abundance, distribution and movements of these birds are largely unknown. In Ontario in summer, these basic- plumaged loons are known to occur in small numbers on large inland lakes (e.g., the Great Lakes) 4,6,7,8 $^{4}$ but the authors imply that they do not continue on to breeding lakes. During autumn migration, loons stage on the lower Great Lakes mainly from August to December, a few lingering into January. They are known to overwinter on the Great Lakes extremely infrequently and in very small numbers (usually< 10 on Lake Ontario Midwinter Waterfowl Count, Kingston to Niagara). ${ }^{9,(\mathrm{D} . T o z u r,}$ pers. comm.) Therefore, there exists the possibility that basicplumaged birds seen in Manitoba in
Wisconsin. ${ }^{10}$ Researchers there found that of the hundreds of loons seen each summer, only one or two would be in basic plumage (J. Mager, pers. comm.). Usually they remain on large lakes used only for foraging, not for breeding. This behaviour of breeding lake avoidance might be expected as territorial pairs are very aggressive towards intruders. ${ }^{10}$ Although hundreds of adults and chicks have been banded in the Wisconsin study area over two decades, a banded loon in basic plumage has not been seen in early summer; these authors suggest that these loons could be "prebreeders" but without marked individuals, one can only speculate as to the age and identity of these birds.

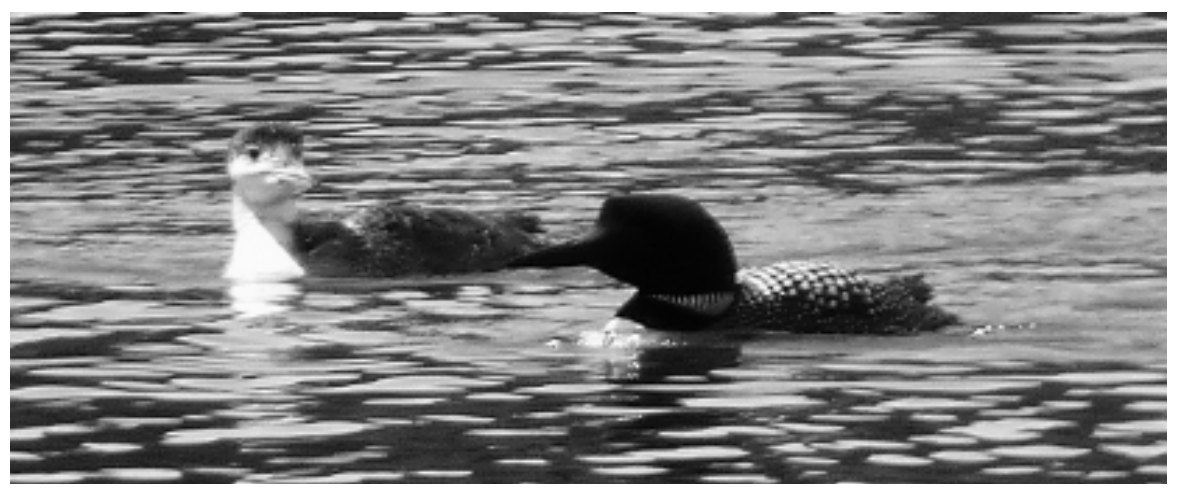

Figure 3 Loons - sub-adult left adult right

- Gervase Orton

spring and summer over-wintered on the Great Lakes. Although this possibility cannot be ruled out, this seems unlikely given the small number observed over-wintering. It seems most likely that the basic-plumaged birds seen in summer in the breeding range over-wintered in the regular (salt water) wintering grounds and returned the following spring (D.Tozur, pers. comm.).

I gathered additional insight on loon behavior from results of a comprehensive study with a large banded population of loons in
I suspect that few birders in Manitoba and in other areas are aware that all or almost all loons seen in breeding plumage in summer are adults at least 3 years of age. The subadult reported here and the other referenced sightings of a basic-plumaged loon in early summer in Manitoba are to my knowledge the only ones reported for Manitoba. A more comprehensive survey would undoubtedly reveal more. In the future, I (and I hope others) will appreciate more fully observations of this species and will be on the lookout for early summer basic-plumaged birds 
so that we might be able to monitor spacial and temporal changes to this segment of the loon population .

\section{Acknowledgements}

My thanks go out to all those individuals who, by their assistance in the writing of this note, have made loons more interesting than they already were. They include Cal Cuthbert (Ducks Unlimited, Brandon), Stuart Houston (Saskatchewan), Kathy Jones (Canadian Lakes Loon Survey, Birds Studies Canada), Ken Kingdon (Parks Canada, Manitoba), Jay Mager (Ohio Northern University), Walter Piper (Chapman University), Theresa Stene (Parks Canada, Saskatchewan), Peter Taylor (Pinawa, Manitoba), Doug Tozer (Bird Studies Canada), Charles Walcott (Cornell University), and Rob Wilson (Saskatchewan). Thanks also to Marg Hammell for reviewing this document and Bruce McLavy for helping with map-making.

\section{Manitoba Avian Research}

Committee (2003) The birds of Manitoba. Manitoba Naturalists Society, Winnipeg MB.

2. Godfrey WE (1966) The birds of Canada. National Museums of Canada Bulletin No 203. Biological Series No 73. Ottawa ON.

\section{Trends from the Breeding Bird} Survey in Canada: Common Loon. (2009) Migratory Birds Conservation Moitoring and Reporting. Canadian Wildlife Service, Environment Canada, Ottawa.

4. Evers DC, Paruk JD, Mcintyre JW, and Barr JF (2010) Common Loon (Gavia immer), The Birds of North America Online (A. Poole, Ed.). Ithaca: Cornell Lab of Ornithology; Retrieved from the Birds of North America Online: http://bna.birds.cornell.edu.cat1.lib.

trentu.ca:8080/bna/species $/ 313$ doi:10.2173/bna.313

5. Evers D, Kaplan JD, Reaman PS, Paruk JD, Phifer P (2000) A demographic characterization of the Common Loon in the upper Great Lakes. Pages 78-90 in Loons: Old history and new findings. Proceedings of a Symposium from the 1997 meeting of the American Ornithologists' Union (McIntyre J W and D Evers, Eds.), North American Loon Fund, Holderness, $\mathrm{NH}$.

6. Palmer RS (1962) Handbook of North American Birds. Vol. 1. Loons through Flamingos. Yale University Press, New Haven, Connecticut.

7. Black JE, Roy KJ (2010) Niagara Birds: a compendium of articles and species accounts of the birds of the Niagara Region in Ontario. Brock University Printing and Digital Services, St. Catherines, ON.

8. Curry R (2006) Birds of Hamilton and surrounding areas. Hamilton Naturalists Club, Hamilton, ON.

9. Sandilands AP (2005) The Birds of Ontario: habitat requirements, limiting factors and status. UBC Press, Vancouver.

10. Walcott C (2010) Loon Behaviour and Calls. In: BirdWatch Canada No 50. Bird Studies Canada, Port Rowan, ON. 